\title{
Exploring the Relation Between Psychotypologies and Article Acquisition
}

\section{Исследование взаимосвязей между психотипологией и употреблением артиклей}

\author{
Martín Testa \\ Ph.D. in Linguistics, \\ Assistant Professor
}

\author{
Мартин Теста \\ кандидат филологических наук, \\ доцент
}

\author{
E-mail: m.testa@uw.edu.pl \\ https://orcid.org/0000-0001-6086-2073 \\ University of Warsaw \\ 8, Oboźna Str., Warsaw, \\ Poland, 00-332 \\ Original manuscript received September 12, 2019 \\ Revised manuscript accepted February 13, 2020
}

\begin{abstract}
The aim of this study is to explore whether there may be any correlations between psychotypology (i.e. perceived linguistic distance) and the number of article-related errors in L1 Polish students of L3 Spanish. Following a survey on the participants' assessment of linguistic distance between the languages of their dominant language constellations, article-related errors were compared by means of a battery of nonparametric Mann-Whitney $U$ tests. The results do not suggest significant differences between groups $B 1$ and $B 2$ in terms of article-related errors. However, positive correlations were found, at an all-encompassing $B 1+B 2$ level, between grammatical psychotypology and article omission errors, and in group B2 with regard to general article use and, more especifically, wrong article use and article omission errors. On the other hand, negative correlations were found between lexical psychotypology and article usage in group B2; phonetic psychotypology and wrong article use in group B1 in group B1; and grammatical psychotypology and unnecessary article use in group $B 1$.
\end{abstract}


The results seem to suggest that perceived linguistic distance among more experienced learners may be linked to the development of successful cross-linguistic associations, whereas it may lead to 'false assumptions' at lower levels of instruction.

Key words: psycholinguistics, psychotypology, article acquisition, L3 Spanish, L1 Polish.

\section{Introduction}

Jean-Marc Dewaele (2010a) has said that motivation the only emotional variable that has been studied in depth in SLA. The great difficulty presented by the analysis of both socio and psycholinguistic variables lies in the fact that, in order to do so, the groups must be as homogeneous as possible, an 'ideal' that most of the time is extremely complicated to achieve.

Currently, Poland offers a relatively homogeneous linguistic landscape. In fact, most Poles have grown up as monolingual speakers of Polish, and have learned English as an L2 at school (Kucharczyk, 2018; Otwinowska, 2016). This allows controlling the variables which are considered to be most important when studying cross-linguistic influence, namely: age; type of motivation; social, educational and cultural background; linguistic background; type and amount of exposure to the target language; target language proficiency; linguistic distance between L1 and the target language; and task type (Jarvis, 2000).

Moreover, this article includes a rarely controlled variable as is psychotypology. According to Kellerman (1977, 1978, 1979a, 1979b), cross-linguistic influence is greater when students perceive less linguistic distance between their mother tongue and target language. In line with Gibson's (1986) theory of affordances, Aronin and Singleton (2012: 180) state that some people do not see opportunities in places or situations where other people do, and that, the fact that an opportunity is perceived does not imply that it will be used. For this reason, we argue that the perception of linguistic proximity between the languages the students' linguistic repertoire could have an impact on both the quantity and the quality of comprehensible input (Krashen, 1982) that students have access to.

The Spanish article system poses one of the most challenging aspects of Spanish grammar for L1 Polish students (Fernández Jódar, 
2006, 2010, 2017; Pawlik, 2001; Testa, in press). Polish lacks an article system, and for this reason L1 Polish students can be argued to have 'nothing to transfer' into L3 Spanish. However, since the perception of linguistic proximity has been found to influence the transfer of linguistic knowledge in multilingual learners (e.g. Kellerman, 1977, 1979b; Otwinowska, 2016) we argue that those Polish students who perceive greater linguistic proximity between their mother tongue and their L3 Spanish will be more likely to establish successful crosslinguistic relations and will thus show a lower ratio of article-related errors.

This article is structured as follows. Section 2 contains a short review of the literature on cross-linguistic influence, multilingualism, linguistic affordances, the concept of psychotypology, as well as an introduction to L1 Polish students' problems with the Spanish article system. Section 3 explains data gathering procedures and the methodology used in the present study. The results follow in Section 4, which are further discussed in Section 5. The article ends with some final remarks in Section 6.

\section{Literature review \\ Contrastive analysis, errors and foreign language learning}

Although the term Contrastive Analysis Hypothesis appears for the first time in Wardhaugh (1970), this technique can be traced back to the works of Charles C. Fries and Robert Lado in the 1940s and 1950s, respectively. Contrastive analysis is based

"on the assumption that we can predict and describe the patterns that will cause difficulty in learning, and those that will not cause difficulty, by comparing systematically the language to be learned with the native language and culture of the student» (Lado, 1957: vii).

In other words, because of its behaviourist matrix, contrastive analysis pressumes heavy L1 transfer and the necessity of acquiring new linguistic habits (cfr. Gass, Behney \& Plonsky, 2013: 85-6; Selinker, 1992: 21). According to Stockwell, Bowen \& Martin's (1965a, 1965b) hierarchy of difficulty, although students are predicted to have no trouble with corresponding forms, they are expected to find increasingly more difficulty (in ascending order) with coalesced, absent, new, and differentiated forms. However, not all interlanguages are alike just as 
no native idiolect is equal to any other, and hence contrastive analysis is highly theoretical, insofar as it is the comparison of two abstract standard varieties ('the comparative fallacy', Bley-Vroman, 1983). Due to much criticism, contrastive analysis and transfer* studies were abandoned to be subsequently

«reappraised at the end of the 1970s and the beginning of the 1980s, together with the growing interest in the positive aspects of transfer and in the area of lexis» (Otwinowska, 2016: 61), i.e. cognate vocabulary. ${ }^{* *}$

A paradigm shift started with Stephen Pit Corder's (1967) article The significance of learners' errors. Corder suggested that errors represented in fact a sort of 'built-in syllabus' to which teachers should learn to adapt, rather than impose upon learners their own preconceptions (p. 169). In Selinker's words:

"errors are necessary 'inbetween stations', important for selfevaluation and, perhaps, therapy» (1992: 119).

Moreover, Corder (1967) distinguished overt from covert errors. As he indicated years later,

"[p]urely superficial formal correctness is no guarantee of absence of error. A learner may produce a superficially well-formed sentence which, when interpreted according to the rules of the target language, does not mean what he intended to mean» (1982: 39).

Something that has aroused much debate in the field of second language acquisition is Krashen's (1982) sharp differentiation between acquisition and learning, the first being a natural and unconscious process while the latter refers to conscious rule memorization. According to Krashen, there is no individual variation in the process of acquisition (natural order hypothesis). Nevertheless, there may be variation in

* Odlin (2016a) notes that the term transfer comes from the translation made by American linguists William Dwight Whitney (transferred) and Aaron Marshall Elliott (influence, transference, and transfer) of two terms (hinübertragen and übertragen) used by German linguists in the 19th century, instead of coming from psychological currents such as behaviorism and, even less, from Weinreich. Going even further, Gass, Behney and Plonsky (2013: 100) point out that the first reference to (phonetic) interferences can be found in the Old Testament, more specifically, the story of Jephthah and the tribe of Ephraim in the Book of Judges (12: 4-6).

** The main reference work in terms of Spanish-Polish contrastive grammar is the recently edited Gramática contrastiva español-polaco (Nowikow, 2017). 
the speed of acquisition as a result of the amount of comprehensible input received by the learner and the strength of the affective filter (e.g. foreign language anxiety). According to Krashen, the affective filter is an umbrella term which covers affective factors such as motivation, anxiety and self-esteem. If the filter is low, the students

«will be more open to the input, and it will strike 'deeper'» (1982: 31).

Otherwise,

"if we are stressed, uncomfortable, self-conscious or unmotivated, we are unlikely to learn very much» (Yule, 2010: 189).

When the affective filter is low, the acquisition device is fed by means of comprehensible input, which needs to match the students' intelligence and aptitudes in order to be more effective (Dörnyei, 2005: 49). Moreover, input (when comprehensible) is predicted to be acquired in kairological ${ }^{*}$ time, that is 'in due time' (Aronin \& Singleton, 2012).

There may also be variation when it comes to performance in the L2, depending on how much the students rely on their «learned» knowledge. According to the use made of the monitor, Krashen distinguishes three types of monitor users: over-users, under-users, and optimal users. The difference between these types of users is specially visible when performing speaking activities: Monitor over-users think 'too much' before they actually say something. This is because the monitor requires time, focus and knowledge of the rule it wants to apply. As a result, monitor over-users have a higher cognitive load

"at the expense of the other production processes of the utterance» (Kormos, 1999: 219).

In fact, not only comprehensible input but the interaction between input and comprehensible output (Swain, 1985) seems to be crucial in the learning process, for it stimulates learning and functions as a catalyst for future interlanguage changes (Fantini, 1985; Gass, Behney \& Plonsky, 2013).

On the other hand, there are authors who argue that learning precedes and results in acquisition (Bialystok, 1979, 1981; Bialystok \& Fröhlich, 1977; Ellis, 1985; Kucharczyk, 2018; McLaughlin, 1978; Sharwood-Smith, 1981; Stevick, 1980). In fact, grammar teaching may

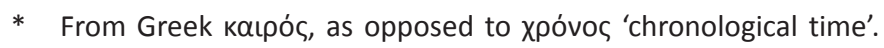


not only accelerate the process but also alter the order of acquisition as a consequence of the automatization of certain processes through practice (cfr. Ellis, 1985: 95; Sharwood-Smith, 1981: 166). Gass, Behney \& Plonsky (2013: 287) underline the importance of practice in automatizing certain behaviors (as is the case with athletes) so that students can devote less energy and attention to certain tasks or linguistic structures. As Kucharczyk (2018: 127) explains, the acquisition of communicative competence in a foreign language implies the passage of a level of declarative knowledge to practical competence. In connection with this, by means of frequent exposure to the target linguistic forms, preferred patterns of language use

«become stabilized through frequency of use and the strengthening of connection weights in neural networks» (Larsen-Freeman, 2007: 783).

As Gass, Behney \& Plonsky (2013: 497-510) explain, input is apperceived by means of frequent exposure, and it becomes comprehended once it is analyzed and understood in all its aspects (i.e. syntax, phonology, pragmatics, etc.). Later, comprehended input may become intake by means of hypothesis formulation and, once hypotheses have been confirmed and reconfirmed, they can be integrated and ready to be used in output.

\section{Language transfer}

One of the most influential concepts in the field of second language acquisition is that of language transfer, also known as cross-linguistic influence (Sharwood-Smith \& Kellerman, 1986), cross-linguistic operation (Singleton, 1996), and cross-linguistic interaction (Herdina \& Jessner, 2002). Transfer has been defined as

"the influence resulting from the similarities and differences between the target language and any other language that has been previously (and perhaps imperfectly) acquired»(Odlin, 1989: 27).

Jarvis supports Odlin's definition and adds that L1 transfer can be said to occur in those instances

«where a statistically significant correlation (or probability-based relation) is shown to exist between some feature of learner's IL performance and their L1 background» (2000: 252). 
Language transfer is an absolutely normal process and is not restricted to contact between two languages. As a matter of fact, it can be the result of either intra-systemic factors (i.e. within one language, as in the case of $* I$ goed for $I$ went) or foreign interference (Otwinowska, 2016: 31). In other words, transfer (i.e. a process) can be either positive or negative (i.e. their products) (Ringbom, 2016: 42). Furthermore, transfer can occur between any of the languages of the learners' linguistic repertoire, at any of the language subsystems ${ }^{*}$, and in any direction (L1 $\leftrightarrow \mathrm{L} 2 \leftrightarrow \mathrm{L} 3$ ) (Jarvis \& Pavlenko, 2008).

Transfer is more frequent at lower levels of learning but is not restricted to them (De Angelis, 2007; Ringbom, 1987). It is also more frequent between languages that are phonetically similar, such as Spanish and Italian (Gass, Behney \& Plonsky, 2013: 150; Ringbom, 1987: 40). However, transfer of cognate vocabulary can take place only after a certain threshold has been achieved (at least one or two years of instruction, De Angelis, 2007: 34) and usually requires training (Kellerman, 1977; Kucharczyk, 2018; Otwinowska, 2016). In fact, positive transfer is something sought after in multilingualism. Kucharczyk's (2018) recently-developed SMART ${ }^{* *}$ model encourages positive transfer as the central element of L3 teaching. Kucharczyk argues that by adopting a reflective attitude, students subsequently compare and 'filter' what is positive and negative in their transfers, causing the latter to disappear over time.

\section{Multilingualism and affordances}

The concept of multiligualism (Aronin \& Singleton, 2012) differs from that one of linguistic repertoire (or multilinguality, Aronin \& Ó Laoire, 2004) in that the main focus of multilingualism is the individual's dominant language constellation $^{* * *}$, whereas the latter

* However, De Angelis (2007) notes that there is little evidence in terms of morphological transfer, as well as little research on syntactical transfer.

** SMART stands for Polish strategie 'strategies', metapoznanie w uczeniu się 'metacognition in learning', afektywność 'affectivity', refleksyjność 'reflection', and transfer 'transfer'.

***Aronin \& Singleton (2012: 74) define it as "an ensemble of languages which in functional terms are closely connected, and which are treated as a constellation on the basis of the criterion that, operating together, they are vehicular for particular individuals or particular groups of people». 
deals with all of the languages known to an individual regardless of their degree of proficiency. It also differs from Cook's concept of multicompetence $(1991,1992,1993,2007)$ because it includes the individual's crosslinguistic awareness, opinions and preferences.

In pursuit of a more comprehensive terminology, Aronin \& Singleton (2012) suggest user instead of speaker, and environment instead of setting. As they expalin, user refers to those «individuals who use, study, or acquire languages», and environment «denotes the time and place where the languages are used» (p. 122). Besides, the term language is applied only to those languages in the user's dominant language constellation.

Much has been written about English as Europe's current lingua franca (e.g. Aronin \& Singleton, 2012; Bono, 2011; Cenoz, 2001; Cenoz \& Jessner, 2000; Jessner, 2006; Otwinowska, 2016; Ringbom, 2011). In Poland, English is «taught from the first classes of primary school» and «becomes a crucial part of Polish speakers' multilingual language constellations» (Otwinowska, 2016: 235-6). Kucharczyk (2018: 150) goes on to claim that English is in most cases Poles' 'first' foreign language. On the other hand, Spanish is often studied either as an L3 or L4. According to statistics from Poland's Ministry of National Education (2018) (Pol. Ministerstwo Edukacji Narodowej), as of 2018 there are about 168,000 learners of Spanish, as opposed to the $+6,000,000$ learners of English, $\approx 2,000,000$ learners of German and $\approx 204,000$ learners of Russian (Kowal, 2019).

Some authors (e.g. Aronin \& Ó Laoire, 2004; Aronin \& Singleton, 2012) suggest addressing the process of multilingualism within a complex, dynamic systems framework (Dynamic Systems Theory, de Bot, 2008). One of the first authors to have dealt with complex adaptive systems in second language acquisition was Diane Larsen-Freeman who explains that the distinctiveness of this type of systems lies in the fact that they

«are dynamic, complex, nonlinear, chaotic, unpredictable, sensitive to initial conditions, open, self-organizing, feedback sensitive, and adaptive» (1997: 142).

The result is something new (possibly unexpected) which arises from the interaction of the components (i.e. agents and/or elements) of a system, as well as from the investments that are made into it (Larsen- 
Freeman \& Cameron, 2008; Larsen-Freeman, 2014). The complexity of this type of systems is clearly illustrated by, for example, the image of a flock of birds, or the weather system (Larsen-Freeman \& Cameron, 2008). Gass, Behney \& Plonsky have brought in the analogy with a kaleidoscope, since

"[a]ny change in the system (a shake or twist to the kaleidoscope) will result in a different unpredictable pattern» (2013: 175).

Multilingual language learning is another example, since it is not a linear process: the learning

«curve is filled with peaks and valleys, progress and backsliding» (Larsen-Freeman, 1997: 151).

Research in the relatively new field of third language acquisition (TLA) has been progressively intensified as of the 2000s (Jessner, Megens \& Graus, 2016: 193). One of the most important differences between SLA and TLA is that the first one deals with only two systems influencing each other, whereas in the latter there are three types of interaction at stake, i.e. L1 $\leftrightarrow \mathrm{L} 2, \mathrm{~L} 1 \leftrightarrow \mathrm{L} 3$, and $\mathrm{L} 2 \leftrightarrow \mathrm{L} 3$ (Jessner 2006). For this reason, the study of interlinguistic influences in this field is potentially more complex than in the field of SLA (Cenoz, 2001: 8). According to Bono (2011: 49),

«L3 learners are sensitive to points of commonality between language systems and are able to exploit them to obtain a target language item and to attend to their production in deliberate and, in some cases, highly sophisticated ways».

While there is evidence that the languages of multilingual speakers can work either together as a single unit or as separate entities (see Aronin \& Singleton, 2012), Cook suggests that the truth probably lies somewhere in the middle:

"total separation is impossible since both languages are in the same mind; total integration is impossible since L2 users can keep the languages apart» (2003: 7).

However, because of the increasing number of competing linguistic systems in the mind, Safont Jordà (2005: 13) suggests that one of the most relevant issues in TLA is that of linguistic maintenance, in other words, that learners «maintain their proficiency level in the languages 
known to them». De Angelis (2007: 12) claims that the elements that should be controlled in TLA studies are: age of acquisition; sequence of acquisition; proficiency levels; exposure to native and non-native language environments; classroom language of instruction; amount of formal instruction; manner of acquisition; context of use; active or passive use; number of languages known to the speaker; as well as productive and receptive skills in each language.

Singleton \& Aronin (2007) suggest using psychologist James J. Gibson's theory of affordances (1986) as a theoretical framework in the study of multilingualism, since the reality of multilinguals provides favorable conditions to develop awareness of both the social and cognitive possibilities 'offered' by their very multilingual status. Initially conceived in the field of visual perception, the theory refers to «the perceived opportunities for action provided for the observer by an environment» (Otwinowska, 2016: 129). ${ }^{*}$ In this way, «[a] fire affords warmth on a cold night, [but] it also affords being burnt»; and «[f]or one of our early ancestors, an approaching rabbit afforded eating whereas an approaching tiger afforded being eaten» (Gibson, 1986: 102). From a multilingual perspective, Aronin and Singleton (2012) bring up the question of the Tatar language in the days of the Tatar Autonomous Soviet Socialist Republic (1920-1990) where, due to political issues, by the end of the 1980 s only $7 \%$ of Tartar children went to Tartar schools, there were 0.7 copies of books in Tatar per person, as well as only 3 hours a week of radio in that language, which resulted in an impressive drop in the acquisition of Tatar. Nowadays, on the other hand, with the advent of widespread internet access an almost unlimited amount of resources are within easy reach. In this context, the key pedagogical challenge is to raise awareness of those resources so that learners can exploit them to the fullest.**

* In linguistics, akin to this theory is Schmidt's noticing hypothesis (1990a, 1990b). Nowadays, there is widespread agreement that selective attention plays a fundamental role in the learning process (Gass, Behney \& Plonsky, 2013: 383).

** Everything seems to indicate that the use of linguistic affordances can be perfected with the accumulation of linguistic experience. As Gibson's notes: «Knowledge of the environment, surely, develops as perception develops, extends as the observers travel, gets finer as they learn to scrutinize, gets longer as they apprehend more events, gets fuller as they see more objects, and gets richer as they notice more affordances» (1986: 253). 


\section{Psychotypology}

Almost fifty years ago, Vildomec rightly noted that "[t]he psychological similarity of two tongues may, but need not, be based on the linguistic» (1971: 19).

In fact, two languages studied at the same time, with similar methods, with the same teacher and used in similar environments can share in the student's mind a psychological link even if these languages are not related typologically.

Currently, there is widespread agreement (e.g. Cenoz, 2001; De Angelis, 2007; Kucharczyk, 2018; Odlin, 2016b; Otwinowska, 2016; Selinker, 1992; Sima Paribakht \& Bingham Wesche, 2016) on the facilitating effect of objective linguistic proximity. ${ }^{*}$ In other words,

«typological proximity between the L1 and the L2 ensures crosslinguistic similarities in many subsystems that can facilitate the learners' task in multiple ways at the same time» (Sima Paribakht \& Bingham Wesche, 2016: 79).

However, similarity can also be found in typologically distant languages. In fact, two given languages can be found to have formal similarity (e.g. in their grammars, lexicons, etc.), regardless of their genetic affiliation (i.e. Romance, Germanic, Slavic, etc.) (De Angelis, 2007: 26).

Nevertheless, Odlin (1989: 142) observes that

«an objective estimation of language distance can sometimes be misleading about the likelihood of transfer: in some cases, the subjective estimation of distance by leaners can override an objective measure» (emphasis in the original).

This is commonly known as psychotypology (Kellerman, 1977, 1979a, 1979b) which can be defined as

"the learner's perception of typological distance between languages (...), which is the individual assessment of the degree of relationship between particular structures and words of L1 and L2» (Otwinowska, 2016: 103).

* Sima Paribakht \& Bingham Wesche (2016: 78) point that "[r]ecent typological analyses of languages have begun to provide a basis for estimating language distance». It is worth noting that the idea that linguistic proximity between languages promotes transfer dates back almost one hundred years (e.g. Skaggs, 1925; Robinson, 1927). 
Kellerman explains that transfer is subject to two main phenomena: projection and retention. That is to say,

«if the learner believes that there could be a relationship between $N L$ and TL at a given point, he may well transfer» (1977: 93).

Conversely, learners will not transfer (i.e. they will avoid transfer, as a strategy) if they do not perceive any similarity between the L1 and the target language. Psychotypology is a highly complex phenomenon, since the perception of linguistic distance is subject to change over time. For example,

"[i]t may be that a learner begins learning a language with the expectation of great similarity, only to find that there are more differences than originally anticipated» (Gass, Behney \& Plonsky, 2013: 152).

Very often, students perceive more linguistic proximity between an L2 and L3, which has come to be known as the foreign language effect (Meisel, 1983) or L2 factor (Williams \& Hammarberg, 1998). According to this theory, due to the high degree of explicit metalinguistic knowledge resulting from the typically formal process of learning foreign languages, the L2 acts as a kind of filter leaving the L1 inaccessible during the process of acquiring the L3, even if the latter are typologically similar (Bardel \& Falk, 2007; Falk, Lindqvist \& Bardel, 2015).

However, the mere perception of cross-linguistic similarity does not necessarily lead to good results. Sanchez (2011: 89) warns that psychotypologies can, in the long term, lead students to assume false similarities (or differences) that, objectively, do not exist. Moreover, Otwinowska (2016: 64) states that the mere perception of similarity between typologically distant languages can lead to a large number of errors, since this influence would be stronger than that of objective interlinguistic similarity.

\section{Polish difficulties when learning L3 Spanish}

Nowikow (2013) points out that at the typological level languages can be of two types, namely Article+Tense or Aspect+Case. In this respect, Spanish and Polish are typologically distant languages. 
Nevertheless, Fernández Jódar (2017) observes that the functions of Spanish articles can be expressed in Polish by means of word order, cases (cfr. Konieczna-Twardzikowa, 1992), aspect, demonstratives, possessives, and lexical choice*, although there are no exact equivalents between Spanish and Polish.* Moreover, the possibility of choosing not only between the definite and indefinite, but also the zero article (Ø) adds an extra layer of difficulty for Polish students (Fernández Jódar, 2017: 355-6). Ringbom (1987) recognizes the difficulty in terms of article acquisition by learners whose L1 does not have such a category and, in his opinion, most of the errors are due to omission. More recently, Ringbom (2016: 39) states that students have a tendency to assign the label 'redundant' to those categories which are absent in their L1 grammars, especially in the initial stages of learning.

By means of analyzing the writings of Polish university students of Spanish, Fernández Jódar (2006) found that the major problems are found in the use of articles, tenses and prepositions. Fernández Jódar claims that article-related errors can be found throughout his corpus, regardless of the task. Moreover, he identified as many as twenty types of article-related error, the most frequent being the unnecessary use of the definite article (see Table 1).

More recently, Testa (in press) analyzed the use of Spanish articles two intermediate level groups of L1 Polish/L2 English multilingual students. The results of the study is in line with George's (1972) theory of redundancy, since students showed a tendency to 'correct' both definite and indefinite articles with the zero article in a grammaticality judgment task. Conversely, for the most part the zero article was not corrected by students, even when necessary. Testa also observes that during the posttask interviews, none of the students pointed to L2 English influence, with the exception of one student who had native-like control of English. The posttask interviews also reveal the necessity for extra caution when analyzing students' article-related errors, since some of those errors may be covert. ${ }^{* *}$ Furthermore, the students' comments

* For example: Spa. ¿Tienes un lápiz? (Pol. Masz długopis?, 'Do you have a spare pencil?'), Spa. ¿Tienes lápiz? (Pol. Chcesz długopis?, 'Would you like a pencil?'), Spa. ¿Tienes el lápiz? (Pol. Masz ten długopis? 'Do you have the/this/that pencil?» (Fernández Jódar, 2010).

** Contrastive analyses can be found in Fernández Jódar (2010, 2017) and Pawlik (2001).

*** For example, one student reported having used a zero article before the word vodka, not by deliberate choice but because she was unsure whether vodka is feminine or masculine in Spanish. 
point to insufficient awareness of the grammatical meaning of Spanish articles, something which has also been observed by Odlin (2016b) with regard to the acquisition of English articles by Finnish L1 students.

Table 1. Types of article-related error (summarized from Fernández Jódar 2006: 99-106)

\begin{tabular}{|c|c|c|}
\hline Wrong use of def & Wrong use of indef & Wrong use of $\varnothing$ \\
\hline $\begin{array}{l}\text { Unnecessary use } \\
(\text { come *la carne })\end{array}$ & $\begin{array}{l}\text { Unnecessary use } \\
\text { (hacer cola durante *unos dias) }\end{array}$ & $\begin{array}{l}\text { def-omission } \\
(\text { en } * \text { _escuela los niños })\end{array}$ \\
\hline $\begin{array}{l}\text { Unnecessary use after 'de' } \\
(\text { cambio *del sexo) }\end{array}$ & $\begin{array}{l}\text { Unnecessary use after 'de' } \\
\text { (de *unos carácteres fuertes) }\end{array}$ & $\begin{array}{l}\text { def-omission } \\
\left.\text { (la vida de }{ }_{-} \text {niños }\right)\end{array}$ \\
\hline $\begin{array}{l}\text { Unnecessary use with proper } \\
\text { nouns } \\
(* \text { la Polonia })\end{array}$ & $\begin{array}{l}\text { Unnecessary use after «como» } \\
\text { (como *una holgazana } \\
\text { perfecta) }\end{array}$ & $\begin{array}{l}\text { def-omission (fixed } \\
\text { phrases) } \\
(\text { de } * \text { teoría } a * \\
\text { práctica) }\end{array}$ \\
\hline $\begin{array}{l}\text { Unnecessary use with determiners } \\
\text { (de *los unos cuantos señores) }\end{array}$ & $\begin{array}{l}\text { Unnecessary use in negatives } \\
\text { (no hacer *unos comentarios) }\end{array}$ & $\begin{array}{l}\text { def-omission (proper } \\
\text { nouns) } \\
\left(*_{-} \text {nueva Polonia }\right)\end{array}$ \\
\hline $\begin{array}{l}\text { def instead of possessive } \\
(* \text { el tío tenía) }\end{array}$ & $\begin{array}{l}\text { indef-for-def (in anaphoras) } \\
\text { (*un auto me golpeó con } \\
\text { fuerza) }\end{array}$ & $\begin{array}{l}\text { indef-omission } \\
(\text { serás } * \text { mujer } \\
\text { independiente) }\end{array}$ \\
\hline $\begin{array}{l}\text { Unnecessary use in metalinguistic } \\
\text { predicates } \\
(\text { significa también *el trabajo) }\end{array}$ & $\begin{array}{l}\text { indef-for-def (unique) } \\
\text { (hacer *un viaje de su vida) }\end{array}$ & $\begin{array}{l}\text { def-omission in subject } \\
\text { position } \\
\left(*_{-}^{*} \text { tiempo pasaba }\right)\end{array}$ \\
\hline \multicolumn{3}{|l|}{$\begin{array}{l}\text { Unnecessary use with professions } \\
\text { (trabajar como *la canguro) }\end{array}$} \\
\hline $\begin{array}{l}\text { def-for-indef (first-mention) } \\
\text { (podia ganar *el viaje a Legoland) }\end{array}$ & & \\
\hline
\end{tabular}

To the best of our knowledge, there are no studies that explore the relation between the concept of psychotypology and the frequency of article-related errors. We argue that those students who perceive closer linguistic proximity between their L1 Polish and L3 Spanish may be more successful at establishing cross-linguistic relations between the Spanish article system and the ways definiteness is expressed in their mother tongue. In light of these considerations this article will address the following research questions:

a) Does the perception of lexical linguistic proximity between Polish and Spanish correlate with a lower/higher ratio of article-related errors? 
b) Does the perception of phonetic linguistic proximity between Polish and Spanish correlate with a lower/higher ratio of article-related errors?

c) Does the perception of grammatical linguistic proximity between Polish and Spanish correlate with a lower/higher ratio of article-related errors?

\section{The study Data and participants}

Studying the interlanguage of a group is an extremely hard task, since the group should be as homogeneous as possible, and in general

"the identity of multilinguals is especially complex, dynamic and unpredictable» (Aronin \& Singleton, 2012: 168).

For example, Ringbom (1987) argues that Finland is an ideal country for the study of transfer, given the bilingual status of the country (both Finnish and Swedish are official languages). On the other hand, our choice of Poland was motivated by observations that it represents one of the most homogeneous linguistic realities in the European context (e.g. Kucharczyk, 2018; Otwinowska, 2016).

Only learners at an intermediate level of instruction were chosen, since lower level students tend to pay attention only to lexical similarities and not so much to grammatical ones (Kucharczyk 2018: 117). As pointed out by Dewaele (2010b), when students have too low or too high a level, knowledge of other languages may not be of greater importance. On the other hand, the intermediate level seems to represent an ideal object for the study of the interaction between multilingualism and the students' use of linguistic affordances (Dewaele, 2010b).

It is worth highlighting the uniformity of the sample, since the participants in this study (all L1 Polish speakers) were all students of a degree either in Philology or Linguistics at the University of Warsaw (ages between 19 and 25). This seemed an ideal context to analyze psychotypologies, given that such a group of individuals have a special sensitivity when evaluating lexical, phonetic and grammatical similarities and differences. Furthermore, while some of them participated in more than one writing task, the data collected in the surveys are very consistent. 
Even though writing tends to reflect a more monitored use of language, we have chosen this way of data gathering with the aim of analyzing individual variation with respect to those errors which persist even during monitored use (Krashen, 1982). Moreover, writing requires greater accuracy and complexity (Robinson, 2001), thus filtering systematic errors from slips and mistakes (Corder, 1967).

The corpus ( $\mathrm{n}=72 ; 15,288$ words) is composed of three different types of writing assignments based on the topics that had already been part of class discussions during the semester. The topics were: Mis mejores vacaciones 'The best holidays I have ever had' $(\mathrm{n}=28)$, an e-mail to a friend telling them some anecdote $(\mathrm{n}=20)$, and Ventajas $y$ desventajas del uso de internet a nivel educativo 'Pros and cons of using internet for educational purposes' $(n=24)$. The first session took place at the end of the winter semester of 2016/2017, the second one before the Easter break during the summer semester of 2016/2017, and the third one at the end of that summer semester. The students had one hour and twenty minutes to perform each writing tasks. Article-related errors were categorized as follows: a) wrong article, b) unnecessary article, c) article omission, and d) wrong lexical category.

\section{Methodology}

The students had to fill out a survey (see Testa, 2018) in order to control the nine variables suggested by Jarvis (2000), plus a new item, i.e. psychotypology. ${ }^{*}$ The surveys were all filled out in class. The students had twenty minutes to fill out the survey.

The first set of questions related to psychotypologies was related to the students' L1 (Pol. Z języków, których używasz, który jest najbardziej zbliżony do języka polskiego? 'Which of the languages you use is the closest to Polish?'). Six groups were formed with the following configurations:

PSI1 (Vocabulary: Polish/Spanish+, n=19)

PSI2 (Vocabulary: Polish/Spanish-, $n=53$ )

PSI3 (Phonetics: Polish/Spanish+, $\mathrm{n}=32$ )

PSI4 (Phonetics: Polish/Spanish-, $\mathrm{n}=40$ )

* The section on psychotypologies was slightly modified, given that two of the questions (i.e. syntax and morphology) could be considered too specific for students. In this survey only three of the questions were used (i.e. vocabulary, phonetics and grammar). 
PSI5 (Grammar: Polish/Spanish+, n=27)

PSI6 (Grammar: Polish/Spanish-, $\mathrm{n}=45$ )
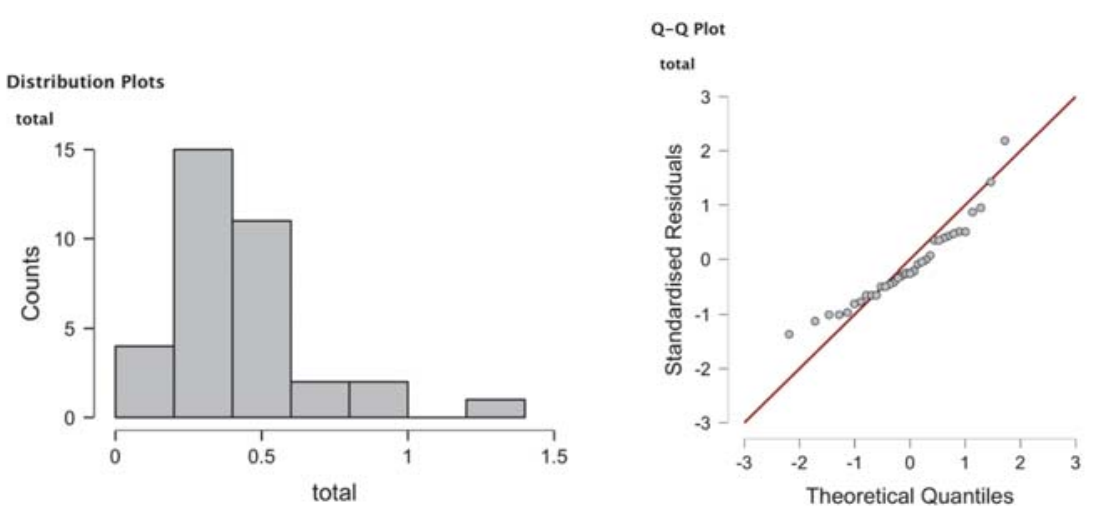

Figure 1. Data distribution in group
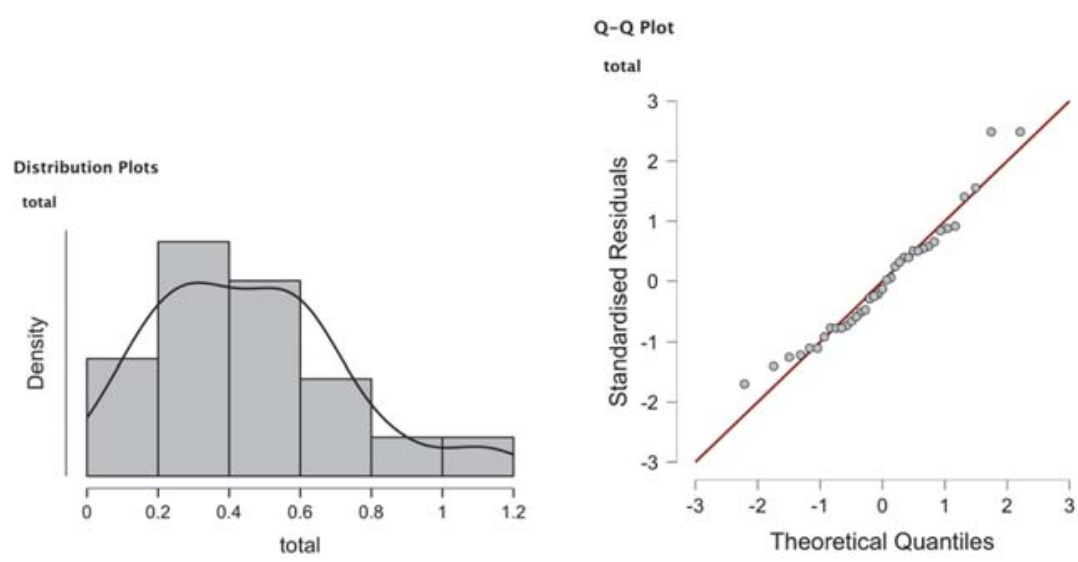

Figure 2. Data distribution in group B2

The second set of questions related to psychotypologies where asked in the form of perceived linguistic proximity to Spanish (L3) (Pol. Który język? Angielski czy polski pomaga Tobie bardziej w nauce hiszpańskiego? 'Which language, English or Polish, is more helpful for learning Spanish?'). Nine groups were formed with the following configurations:

PSI7 (Vocabulary: Polish+, $\mathrm{n}=6$ )

PSI8 (Vocabulary: English+, $\mathrm{n}=65$ )

PSI9 (Vocabulary: None, $\mathrm{n}=1$ ) 
PSI10 (Phonetics: Polish+, $\mathrm{n}=53$ )

PSI11 (Phonetics: English+, n=16)

PSI12 (Phonetics: None, $\mathrm{n}=3$ )

PSI13 (Grammar: Polish+, n=14)

PSI14 (Grammar: English+, n=55)

Two Shapiro-Wilk tests were run on JASP software (version 0.11) (Department of Psychological Methods, University of Amsterdam) in order to determine the normality of data distribution in groups B1 and B2. As can be seen on the distribution and Q-Q plots (Figues 1 and 2, above), the data is not normally distributed neither in group B1 $(\mathrm{n}=35)$ $(W 0.852<1, p<0.001)$ nor in group $\mathrm{B} 2(\mathrm{n}=37)(W 0.957<1, p 0.161)$.

Due to the non-normalized nature of the data collected in the present work, the possibility of performing parametric tests was ruled out, opting for a non-parametric Mann-Whitney $U$ test instead.

\section{Results}

In order to analyze the number of article-related errors, it has been necessary to divide the number of errors by the total production of each category, thus obtaining an error coefficient with a value between 0 and 1 . In this way, if a student omits 2 articles in a total of 14 article environments then the error coefficient in that case will be 0.14 .

In group B1, article-related errors have the highest ratio of error in all three assignments ( 0.43 errors/article in the first assignment, 0.42 errors/article in the second assignment and 0.38 errors/article in the third assignment), the most frequent being wrong article choice and article omission (assignments \# 1, \# 2 and \# 3). This is in line with Geoge's (1972) theory of redundancy, which suggests that students of an L2 will consider the elements which do not exist in their L1 redundant in the L2. In the third assignment article omission and unnecessary use of the article are the most frequent, especially before the adjective otro/a 'other' (e.g. *una otra ciudad; *una otra forma de diversión; *un otro problema).*

Article-related errors have also the highest ratio of error in the B2 group (0.46 in the first assignment, 0.34 in the second assignment

* This construction, however, resembles English another city (an + other) and Italian un'altra città. 
and 0.36 in the third assignment), the most frequent being article omission (assignment \# 1), unnecessary article use and article omission (assignment \# 2), and unnecessary article use (assignment \# 3).

Table 2. Total number of article-related errors in groups B1 and B2 per assignment

\begin{tabular}{ccccccccc}
\hline & \multicolumn{3}{c}{ B1 } & & \multicolumn{3}{c}{ B2 } \\
& \# 1 & $\mathbf{\# ~ 2}$ & $\mathbf{\# ~ 3}$ & Total & $\# \mathbf{~ 1}$ & $\# \mathbf{2}$ & $\mathbf{\# ~ 3}$ & Total \\
\hline & $112 / 260$ & $52 / 125$ & $131 / 341$ & $295 / 726$ & $201 / 439$ & $47 / 137$ & $117 / 323$ & $365 / 899$ \\
a) & 38 & 16 & 19 & 73 & 47 & 9 & 26 & 82 \\
b) & 26 & 16 & 52 & 94 & 53 & 17 & 50 & 120 \\
c) & 37 & 17 & 49 & 103 & 93 & 19 & 37 & 149 \\
d) & 7 & 3 & 11 & 22 & 8 & 2 & 4 & 14 \\
\hline
\end{tabular}

A Mann-Whitney U test found no statistically significant differences between groups B1 and B2 in terms of their frequency of article-related errors (see Table 3). The rank-biserial correlation (rB) suggests a very small effect size in all cases. Nevertheless, it is interesting to not that the median values, though not significant, are higher in group B1 only with regard to wrong article use and wrong lexical category. On the other hand, those students in group B2 produced a slightly higher frequency of errors in terms of general article use, unnecessary article use and article omission.

Table 3. Mann-Whitney U test results (B1 vs. B2)

\begin{tabular}{lcccc}
\hline & $\mathbf{U}$ & $\mathbf{p}$ & Hodges-Lehmann Estimate & Rank-Biserial Correlation \\
\hline total & 632.5 & .870 & -.010 & -.023 \\
a) & 719 & .421 & .020 & .110 \\
b) & 616 & .726 & -.010 & -.049 \\
c) & 627 & .821 & $-1.919 \mathrm{e}-5$ & -.032 \\
d) & 706.5 & .438 & $2.697 \mathrm{e}-5$ & .091 \\
\hline
\end{tabular}

Table 4. Group descriptives B1 vs. B2

\begin{tabular}{lccccc}
\hline & Group & N & Mean & SD & SE \\
\hline total & B1 & 35 & .452 & .250 & .042 \\
& B2 & 37 & .455 & .267 & .044 \\
a) & B1 & 35 & .111 & .108 & .018 \\
\hline
\end{tabular}


Exploring the Relation Between Psychotypologies and Article...

\begin{tabular}{llllll}
\hline & & & & \\
\hline & B2 & 37 & .092 & .091 & .015 \\
$b)$ & B1 & 35 & .127 & .082 & .014 \\
& B2 & 37 & .143 & .117 & .019 \\
c) & B1 & 35 & .185 & .188 & .032 \\
& B2 & 37 & .201 & .218 & .036 \\
d) & B1 & 35 & .029 & .048 & .008 \\
& B2 & 37 & .017 & .031 & .005 \\
\hline
\end{tabular}

\section{Psychotypologies (I)}

A Mann-Whitney $U$ test showed that perceived linguistic proximity between L1 Polish and L3 Spanish in terms of vocabulary (i.e. lexical psychotypology) does not correlate with the frequency of article-related errors, nor with any of the error subtypes, at the B1 level nor at an all-encompassing B1+B2 level (see Table 5). In general, the median values are slightly higher (though not significant) in group PSI2 in all cases except for unnecessary article use $(\mathrm{B} 1+\mathrm{B} 2 ; \mathrm{B} 1)$, and wrong article use (B1) (see Annex 1.1, 1.2, and 1.3). The rank-biserial correlation (rB) (which is interpreted in the same way as Pearson's $r$ ) suggests very small to small effect size in almost all cases. However, a significant correlation was found at the B2 level ( $U$ 87.5, $p$ 0.044) when it comes to the total of article-related errors (see Table 5), where those students who perceived linguistic proximity between Polish and Spanish $(M d n=0.336)$ produced significantly less errors than those who did not $(M d n=0.512)$. Furthermore, in this case the rank-biserial correlation indicates a medium effect size.

Table 5. Mann-Whitney U test results (lexical psychotypology)

\begin{tabular}{cccccc}
\hline \multicolumn{1}{c}{} & $\mathbf{U}$ & $\mathbf{p}$ & Hodges-Lehmann Estimate & Rank-Biserial Correlation \\
\hline$B 1+B 2$ & & 384.500 & .130 & -.090 & -.236 \\
& a) & 485.500 & .822 & $-3.472 \mathrm{e}-5$ & -.036 \\
& b) & 572.500 & .381 & .020 & .137 \\
& c) & 366.000 & .080 & -.050 & -.273 \\
& d) & 388.000 & .084 & $-2.866 \mathrm{e}-5$ & -.229 \\
$B 1$ & & 107.000 & .726 & .022 & .092 \\
& a) & 131.000 & .178 & .050 & .337 \\
& b) & 136.500 & .117 & .060 & .393 \\
\hline
\end{tabular}


Дослідження взаємозв'язків між психотипологією та вживанням...

\begin{tabular}{cccccc}
\hline & c) & 71.000 & .274 & -.054 & -.276 \\
& d) & 69.000 & .175 & $-1.029 \mathrm{e}-5$ & -.296 \\
& & 87.500 & .044 & -.170 & -.417 \\
& a) & 113.500 & .239 & -.031 & -.243 \\
& b) & 147.000 & .935 & $-7.646 \mathrm{e}-5$ & -.020 \\
& c) & 108.500 & .183 & -.060 & -.277 \\
& d) & 123.500 & .310 & $-1.082 \mathrm{e}-6$ & -.177 \\
\hline
\end{tabular}

Later, we proceeded to analyze perceived linguistic proximity between L1 Polish and L3 Spanish in terms of phonetics (i.e. phonetic psychotypology). A Mann-Whitney $\mathrm{U}$ test found no significant differences were found at levels B2 and B1+B2 (see Table 6). Though not significant, the median values are higher in group PSI3 in terms of general article use (B1; $\mathrm{B} 2$; $\mathrm{B} 1+\mathrm{B} 2)$, wrong article use $(\mathrm{B} 1 ; \mathrm{B} 2$; $\mathrm{B} 1+\mathrm{B} 2)$, unnecessary article use $(\mathrm{B} 1 ; \mathrm{B} 2 ; \mathrm{B} 1+\mathrm{B} 2)$ and article omission errors (B2), whereas group PSI4 scores slightly higher in the cases of article omission errors (B1; B1+B2), and wrong lexical category (B1; $\mathrm{B} 2$; B1+B2) (see Annex 1.1, 1.2, and 1.3). The rank-biserial correlation suggests very small to small effect size in all cases. However, a significant correlation ( $U$ 213.5, $p$ 0.047) was found at the B1 level between perceived phonetic proximity between L1 Polish and L3 Spanish and a higher frequency of wrong article use (PSI3 $M d n=0.153$, whereas PSI4 $M d n=0.072$ ) (see Table 6).

Table 6. Mann-Whitney U test results (phonetic psychotypology)

\begin{tabular}{cccccc}
\hline \multicolumn{1}{c}{} & $\mathbf{U}$ & $\mathbf{p}$ & Hodges-Lehmann Estimate & Rank-Biserial Correlation \\
\hline$B 1+B 2$ & & 700.000 & .500 & .040 & .094 \\
& a) & 797.000 & .075 & .030 & .245 \\
& b) & 782.500 & .107 & .030 & .223 \\
& c) & 620.500 & .829 & $-3.63 \mathrm{e}-5$ & -.030 \\
& d) & 508.500 & .080 & $-8.160 \mathrm{e}-6$ & -.205 \\
$B 1$ & & 156.000 & .934 & .006 & .020 \\
& a) & 213.500 & .047 & .050 & .395 \\
& b) & 191.000 & .215 & .040 & .248 \\
& c) & 124.500 & .355 & -.050 & -.186 \\
& d) & 123.500 & .269 & $-5.010 \mathrm{e}-5$ & -.193 \\
\hline
\end{tabular}


Exploring the Relation Between Psychotypologies and Article...

$\begin{array}{lllcl}\text { a) } & 176.000 & .743 & 6.382 \mathrm{e}-5 & .067 \\ \text { b) } & 202.000 & .257 & .030 & .224 \\ \text { c) } & 190.000 & .448 & .040 & .152 \\ \text { d) } & 125.500 & .147 & -3.006 \mathrm{e}-5 & -.239\end{array}$

Finally, a higher number of statistically significant differences were found with regard to grammatical psychotypology. A MannWhitney $U$ test showed that perceived grammatical proximity between L1 Polish and L3 Spanish correlated significantly with a lower frequency of article omission errors $(U 422.5, p$ 0.032) in group $\mathrm{B} 1+\mathrm{B} 2$, but with a higher frequency of unnecessary article use in group B1 ( $U$ 198, $p$ 0.038) (PSI5 $M d n=0.166$; PSI6 $M d n=0.107$ ) (see Table 7). Moreover, in group B2, grammatical psychotypology correlated with a lower frequency of article-related errors in general ( $U$ 89.5, $p$ 0.020) (PSI $M d n=0.346$; PSI6 $M d n=0.529$ ), wrong article use ( $U$ 100.5, $p$ 0.046) (PSI5 $M d n=0.048$; PSI6 $M d n=0.122)$, and article omission errors ( $U$ 98.5, p. 0.041) (PSI5 $M d n=0.159$; PSI6 $M d n=0.229$ ) (see Table 7). The rank-biserial correlation shows a very small effect size in most cases, and a medium effect size in the case of unnecessary article use (B1), the total number of article-related errors (B2) and article omission errors (B2) (see Table 7).

Table 7. Mann-Whitney U test results (grammatical psychotypology)

\begin{tabular}{cccccc}
\hline \multicolumn{1}{c}{} & & $\mathbf{U}$ & $\mathbf{p}$ & Hodges-Lehmann Estimate & Rank-Biserial Correlation \\
\hline$B 1+B 2$ & & 470.000 & .111 & -.100 & -.226 \\
& a) & 507.500 & .245 & -.020 & -.165 \\
& b) & 661.000 & .537 & .010 & .088 \\
& c) & 422.500 & .032 & -.070 & -.305 \\
& d) & 586.500 & .779 & $-9.721 \mathrm{e}-6$ & -.035 \\
$B 1$ & & 153.500 & .602 & .027 & .112 \\
& a) & 160.500 & .443 & .020 & .163 \\
& b) & 198.000 & .038 & .070 & .435 \\
& c) & 112.500 & .384 & -.047 & -.185 \\
& d) & 126.000 & .645 & $-3.034 \mathrm{e}-5$ & -.087 \\
$B 2$ & & 89.500 & .020 & -.210 & -.458 \\
& a) & 100.500 & .046 & -.070 & -.391 \\
& b) & 134.500 & .352 & -.030 & -.185 \\
\hline
\end{tabular}


Дослідження взаємозв'язків між психотипологією та вживанням...

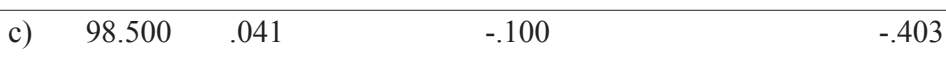

d) $\quad 165.500 \quad 1.000 \quad 3.991 \mathrm{e}-5 \quad .003$

\section{Psychotypologies (II)}

With regard to lexical psychotypology, due to the huge differences in the sample size of groups PSI7 $(n=6)$, PSI8 $(n=65)$, and PSI9 $(n=1)$, a Mann-Whitney $U$ test was carried out in order to compare only groups PSI7 and PSI8. A Mann-Whitney U test showed no statistically significant differences were found in any case (see Table 8). In general, group PSI8's median values are slightly higher than group PSI7's except in the case of article omission errors $(\mathrm{B} 1+\mathrm{B} 2)$, wrong article use (B2), and unnecessary article use (B2) (see Annex 2.1, 2.2, and 2.3), although the differences are not significant. The rank-biserial correlation values suggest very small to small effect size in all cases. It needs to be noted that at the B2 level, wrong lexical category was not available for statistical comparison, due to the fact that the mean value for PSI7 was 0.000 .

Table 8. Mann-Whitney U test results (lexical psychotypology)

\begin{tabular}{cccccc}
\hline \multicolumn{1}{c}{} & & $\mathbf{U}$ & $\mathbf{p}$ & Hodges-Lehmann Estimate & Rank-Biserial Correlation \\
\hline$B 1+B 2$ & & 177.500 & .725 & -.048 & -.090 \\
& a) & 217.500 & .647 & .017 & .115 \\
& b) & 226.500 & .521 & .020 & .162 \\
& c) & 159.000 & .462 & -.050 & -.185 \\
& d) & 157.500 & .370 & $-9.471 \mathrm{e}-5$ & -.192 \\
$B 1$ & & 42.500 & .768 & -.020 & -.115 \\
& a) & 52.500 & .813 & .010 & .094 \\
& b) & 51.000 & .883 & .010 & .063 \\
& c) & 47.000 & .976 & $-2.161 \mathrm{e}-5$ & -.021 \\
& d) & 45.000 & .865 & $-4.942 \mathrm{e}-5$ & -.063 \\
& & 46.000 & .864 & -.080 & -.071 \\
& a) & 52.000 & .908 & $5.328 \mathrm{e}-5$ & .051 \\
& b) & 63.500 & .438 & .070 & .283 \\
& c) & 35.000 & .422 & -.070 & -.293 \\
& d) & $\mathrm{NaN}$ & & & \\
\hline
\end{tabular}


Also in the context of phonetic psychotypologies, no significant differences were found in any case between groups PSI10 and PSI11 (see Table 9). Though not significant, the mean values are a little higher in group PSI11 in the case of wrong article use $(\mathrm{B} 1+\mathrm{B} 2)$ and unnecessary article use $(\mathrm{B} 2 ; \mathrm{B} 1+\mathrm{B} 2)$, but they are slightly higher in group PSI10 in terms of general article-related errors (B1; B2; B1+B2), wrong article use (B2), article omission errors (B1; B2; B1+B2) and wrong lexical category (B1; B2; B1+B2) (see Annex 2.1, 2.2, and 2.3). The rank-biserial correlation indicates a very small to small effect size in all cases (see Table 9).

Table 9. Mann-Whitney U test results (phonetic psychotypology)-1

\begin{tabular}{cccccc}
\hline \multicolumn{1}{c}{$B 1+B 2$} & & $\mathbf{U}$ & $\mathbf{p}$ & Hodges-Lehmann Estimate & Rank-Biserial Correlation \\
\hline & & 406.000 & .803 & -.010 & -.042 \\
& a) & 371.500 & .457 & -.010 & -.124 \\
& b) & 446.500 & .754 & .010 & .053 \\
& c) & 430.000 & .938 & $1.541 \mathrm{e}-5$ & .014 \\
& d) & 477.500 & .369 & $1.857 \mathrm{e}-5$ & .126 \\
$B 1$ & & 100.000 & .762 & -.020 & -.074 \\
& a) & 85.000 & .361 & -.050 & -.213 \\
& b) & 94.500 & .599 & -.020 & -.125 \\
& c) & 120.500 & .627 & .020 & .116 \\
& d) & 130.000 & .313 & $6.048 \mathrm{e}-6$ & .204 \\
$B 2$ & & 101.000 & 1.000 & $-5.246 \mathrm{e}-5$ & -.005 \\
& a) & 99.000 & .936 & $-4.158 \mathrm{e}-5$ & -.025 \\
& b) & 125.500 & .346 & .030 & .236 \\
& c) & 92.000 & .719 & -.020 & -.094 \\
& d) & 108.000 & .769 & $4.264 \mathrm{e}-5$ & .064 \\
\hline
\end{tabular}

Finally, a Mann-Whitney U test reported no significant differences in terms of grammatical psychotypology in any case (see Table 10). In general, mean values are higher in group PSI14 with regard to articlerelated errors in general $(\mathrm{B} 1 ; \mathrm{B} 2 ; \mathrm{B} 1+\mathrm{B} 2)$, wrong article use (B1; $\mathrm{B} 2 ; \mathrm{B} 1+\mathrm{B} 2)$ and article omission errors $(\mathrm{B} 1 ; \mathrm{B} 2 ; \mathrm{B} 1+\mathrm{B} 2)$, but they are higher in group PSI13 with regard to unnecessary article use (B1; $\mathrm{B} 1+\mathrm{B} 2)$ and wrong lexical category (B1; B2; B1+B2) (see Annex 2.1, 2.2, and 2.3). Nevertheless, the differences are not statistically 
significant. The rank-biserial correlation values indicate very small to medium effect size (see Table 10).

Table 10. Mann-Whitney U test results (grammatical psychotypology)

\begin{tabular}{cccccc}
\hline \multicolumn{1}{c}{$B 1+B 2$} & & $\mathbf{U}$ & $\mathbf{p}$ & Hodges-Lehmann Estimate & Rank-Biserial Correlation \\
\hline & & 292.000 & .167 & -.100 & -.242 \\
& a) & 298.000 & .195 & -.030 & -.226 \\
& b) & 422.500 & .580 & .013 & .097 \\
& c) & 302.000 & .217 & -.044 & -.216 \\
& d) & 413.000 & .620 & $4.562 \mathrm{e}-5$ & .073 \\
& & 102.000 & .824 & -.021 & -.056 \\
& a) & 88.500 & .441 & -.023 & -.181 \\
& b) & 141.500 & .181 & .040 & .310 \\
& c) & 102.500 & .840 & -.010 & -.051 \\
& d) & 119.500 & .596 & $5.043 \mathrm{e}-7$ & .106 \\
& & 38.000 & .074 & -.210 & -.510 \\
& a) & 44.000 & .129 & -.050 & -.432 \\
& b) & 66.500 & .630 & -.020 & -.142 \\
& c) & 42.000 & .109 & -.080 & -.458 \\
& d) & 72.000 & .779 & $-1.824 \mathrm{e}-5$ & -.071 \\
\hline
\end{tabular}

\section{Discussion}

One aspect is evident from the results of this study. It is striking that the way of framing the questions on psychotypology seems to have been decisive in the way the students related to those questions, although the idea behind them is arguably the same: to assess perceived linguist distance between the languages of the participants' dominant language constellations. As a matter of fact, statistically significant relations were found with regard to the first set of questions, i.e. perceived linguistic distance in terms of the students' L1, whereas no correlations were found in the second set of questions, i.e. perceived linguistic distance in terms of the students' L3. Furthermore, the results of the statistical tests show the complexity of psychotypologies, given that in some cases psychotypologies seem to have had a facilitating effect while in others they resulted in a higher frequency of errors.

The results do not suggest significant differences between groups B1 and B2 in terms of article-related errors. However, this could be 
explained by the fact that neither group B1 nor B2 were completely homogeneous in terms of proficiency, motivation and the psycholinguistic background of their participants.

Positive correlations were found, at an all-encompassing B1+B2 level, between the grammatical psychotypology and article omission errors ( $p$ 0.032), and in group B2 with regard to general article use ( $p$ 0.020) and, more especifically, wrong article use $(p 0.046)$ and article omission errors $(p$ 0.041). Moreover, a positive correlation was also found between the lexical psychotypology and general article use in group B2 ( $p$ 0.044). On the other hand, negative correlations were found between the phonetic psychotypology and wrong article use in group B1 ( $p$ 0.047); and the grammatical psychotypology and unnecessary article use in group B1 ( $p$ 0.038).

In light of these results, it seems difficult to assert whether perceived linguistic proximity between Polish and Spanish has a general positive effect in the use of L3 Spanish articles. It seems evident that perceived grammatical proximity in more experienced learners (B2) correlated with a general better command of the Spanish article system, probably because those learners are more likely to establish successful crosslinguistic associations between the use of Spanish articles and their syntactic and lexical 'equivalents' in Polish. This may also explain why a positive correlation was found with regard to article omission errors: for these students the article system is probably a less 'redundant' element of Spanish language. Furthermore, positive correlations were found especially in group B2, thus suggesting that cross-linguistic links need time to develop. As Otwinowska points out,

«lower levels of proficiency in L2 and L3 allow only for limited cross-language activation in language production» (2016: 108).

On the other hand, in less experienced learners (B1) perceived linguistic proximity between Polish and Spanish correlated with a significantly higher frequency of article-related errors. It needs to be borne in mind that the students' L2, i.e. English, is a [+ART] language and the lack of perceived linguistic proximity between English and Spanish may have resulted in the students' having 'false assumptions' which eventually led to a higher frequency of article-related errors. Finally, the correlation between the grammatical psychotypology and unnecessary article use in group B1 may be explained by the fact that 
a morpheme that was once redundant (i.e. at levels A1/A2) is now noticed by students and therefore used even in unnecessary contexts.

\section{Conclusion}

The main objective of this study was to explore the role of psychotypology in the frequency of L1 Polish students of L3 Spanish article-related errors. As we have already mentioned, the results of the statistical tests show the complexity of the concept of psychotypology.

The most striking results were found in the context of grammatical psychotypology. The data from this study seems to suggest that perceived linguistic distance among more experienced learners may be linked to successful cross-linguistic associations, whereas at lower levels of instruction it can lead to the development of 'false assumptions'.

Finally, the present study would benefit from further research on the relation between psychotypologies and unmonitored speech (e.g. interviews), since it is argued to have greater internal consistency (Ellis, 1985). Moreover, it would be interesting to see how psychotypologies evolve at different levels of instruction.

\section{References}

Aronin, L., \& Ó Laoire, M. (2004). Exploring multilingualism in cultural contexts: Towards a notion of multilinguality. In Charlotte Hoffmann \& Johannes Ytsma (Eds.), Trilingualism in Family, School and Community (pp. 11-29). Clevedon: Multilingual Matters. https://doi.org/10.21832/9781853596940-002

Aronin, L., \& Singleton, D. (2012). Multilingualism. Philadelphia: John Benjamins Publishing Company. https://doi.org/10.1075/impact.30

Bardel, C., \& Falk, Y. (2007). The role of the second language in third language acquisition: The case of Germanic syntax. Second Language Research, 23 (4), 459-484. https://doi.org/10.1177/0267658307080557

Bialystok, E. (1979). An analytical view of second language competence: a model and some evidence. The Modern Language Journal, 63, 257-262. https://doi. org/10.1111/j.1540-4781.1979.tb02455.x

Bialystok, E. (1981). Some evidence for the integrity and interaction of two knowledge sources. In Roger Andersen (Ed.), New Dimensions in Second Language Acquisition Research (pp. 62-74). Rowley: Newbury House.

Bialystok, E., \& Fröhlich, M. (1977). Aspects of second language learning in classroom setting. Working Papers on Bilingualism, 13, 2-26.

Bley-Vroman, R. (1983). The comparative fallacy in interlanguage studies: The case of systematicity. Language Learning, 33, 1-17. https://doi. org/10.1111/j.1467-1770.1983.tb00983.x 
Bono, M. (2011). Cross-linguistic interaction and metalinguistic awareness in third language acquisition. In Gessica De Angelis \& Jean-Marc Dewaele (Eds.), New Trends in Cross-Linguistic Influence and Multilingualism Research (pp. 25-52). Bristol: Multilingual Matters. https://doi.org/10.21832/9781847694430-004

Cenoz, J. (2001). The effect of linguistic distance, L2 status and age on crosslinguistic influence in the third language. In Jasone Cenoz, Britta Hufeisen \& Ulrike Jessner (Eds.), Cross-linguistic Influence in Third Language Acquisition: Psycholinguistic Perspectives (pp. 8-20). Clevedon: Multilingual Matters. https:// doi.org/10.21832/9781853595509-002

Cenoz, J., \& Jessner, U. (2000). English in Europe: The Acquisition of a Third Language. Clevedon: Multilingual Matters.

Cook, V. (1991). The poverty-of-the-stimulus argument and multicompetence. Second Language Research, 7, 103-117. https://doi.org/10.1177/026765839100700203

Cook, V. (1992). Evidence for multi-competence. Language Learning, 42 (4), $557-$ 591. https://doi.org/10.1111/j.1467-1770.1992.tb01044.x

Cook, V. (1993). Linguistics and Second Language Acquisition. London: Macmillan. https://doi.org/10.1007/978-1-349-22853-9

Cook, V. (2003). Introduction: The changing L1 in the L2 user's mind. In Vivian Cook (Ed.), Effects of the Second Language on the First (pp. 1-18). Bristol: Multilingual Matters. https://doi.org/10.21832/9781853596346-003

Cook, V. (2007). The goals of ELT: Reproducing native-speakers or promoting multicompetence among second language users?. In Jim Cummins \& Chris Davison (Eds.), International Handbook of English Language Teaching (pp. 237248). New York: Springer. https://doi.org/10.1007/978-0-387-46301-8 18

Corder, S.P. (1967). The significance of learners' errors. International Review of Applied Linguistics in Language Teaching, 5 (4), 161-170. https://doi. org/10.1515/iral.1967.5.1-4.161

Corder, S.P. (1982). Error Analysis and Interlanguage. Oxford: Oxford University Press.

De Angelis, G. (2007). Third or Additional Language Acquisition. Clevedon: Multilingual Matters. https://doi.org/10.21832/9781847690050

de Bot, K. (2008). Introduction: second language development as a dynamic process. The Modern Language Journal, 92 (2), 166-178. https://doi.org/10.1111/j.15404781.2008.00712.x

Dewaele, J-M. (2010a). Emotions in Multiple Languages. London: Palgrave Macmillan. https://doi.org/10.1057/9780230289505

Dewaele, J-M. (2010b). Multilingualism and affordances: Variation in self-perceived communicative competence and communicative anxiety in French L1, L2, L3 and L4. IRAL, 48, 105-129. https://doi.org/10.1515/iral.2010.006

Dörnyei, Z. (2005). The Psychology of the Language Learner: Individual Differences in Second Language Acquisition. Mahwah: Lawrence Erlbaum.

Ellis, R. (1985). Understanding Second Language Acquisition. Oxford: Oxford University Press.

Falk, Y., Lindqvist, C., \& Bardel, C. (2015). The role of L1 explicit metalinguistic knowledge in L3 oral production at the initial state. Bilingualism: Language and Cognition, 18, 227-235. https://doi.org/10.1017/S1366728913000552

Fantini, A. (1985). Language Acquisition of a Bilingual Child: A Sociolinguistics Perspective. Clevedon: Multilingual Matters.

Fernández Jódar, R. (2006). Análisis de errores léxicos, morfosintácticos, y gráficos en la lengua escrita de los aprendices polacos de español. Poznań: Adam Mickiewicz University dissertation. 
Fernández Jódar, R. (2010). Gramática frente a pragmática en la descripción del uso del artículo en español y su representación en polaco. Kwartalnik Neofilologiczny, 57 (2), 109-114.

Fernández Jódar, R. (2017). El artículo. In Wiaczeslaw Nowikow (Ed.), Gramática contrastiva español-polaco (pp. 353-377). Łódź: Wydawnictwo Uniwersytetu Łódzkiego.

Gass, S., Behney, J., \& Plonsky, L. (2013). Second Language Acquisition: An Introductory Course. New York: Routledge. https://doi.org/10.4324/9780203137093

George, H. (1972). Common Errors in Language Learning. Rowley: Newbury House.

Gibson, J.J. (1986). The Ecological Approach to Perception. Hillsdale: Lawrence Erlbaum Associates.

Herdina, P., \& Jessner, U. (2002). A Dynamic Model of Multilingualism: Perspectives of Change in Psycholinguistics. Clevedon: Multilingual Matters. https://doi. org/10.21832/9781853595547

Jarvis, S. (2000). Methodological rigor in the study of transfer: Identifying L1 influence in the interlanguage lexicon. Language Learning, 50 (2), 245-309. https://doi.org/10.1111/0023-8333.00118

Jarvis, S., \& Pavlenko, A. (2008). Crosslinguistic Influence in Language and Cognition. New York: Routledge. https://doi.org/10.4324/9780203935927

Jessner, U. (2006). Linguistic Awareness in Multilinguals: English as a Third Language. Edinburgh: Edinburgh University Press. https://doi.org/10.3366/edinbu $\mathrm{rgh} / 9780748619139.001 .0001$

Jessner, U., Megens, M., \& Graus, S. (2016). Crosslinguistic influence in third language acquisition. In Rosa Alonso Alonso (Ed.), Crosslinguistic Influence in Second Language Acquisition (pp. 193-214). Bristol: Multilingual Matters. https://doi.org/10.21832/9781783094837-012

Kellerman, E. (1977). Towards a characterisation of the strategy of transfer in second language learning. Interlanguage Studies Bulletin, 2 (1), 58-145.

Kellerman, E. (1978). Giving learners a break: Native language intuitions as a source of predictions about transferability. Working Papers on Bilingualism, 15, 59-92.

Kellerman, E. (1979a). The problem with difficulty. Interlanguage Studies Bulletin, 4 (1), 27-48.

Kellerman, E. (1979b). Transfer and non-transfer: Where are we now. Studies in Second Language Acquisition, 2, 37-57. . https://doi.org/10.1017/S0272263100000942

Konieczna-Twardzikowa, J. (1992). Caso y definitud en la lengua española desde la perspectiva polaca. Estudios Hispánicos, 2, 171-175.

Kormos, J. (1999). The effect of speaker variables on the self-correction behavior of L2 learners. System, 27, 207-221. https://doi.org/10.1016/S0346-251X(99)00017-2

Kowal, I. (2019). Motywacja do studiowania filologii szwedzkiej jako filologii rzadkiej. Języki Obce w Szkole, 3, 37-41.

Krashen, S. (1982). Principles and Practice in Second Language Acquisition. London: Pergamon.

Kucharczyk, R. (2018). Nauczanie języków obcych a dydaktyka wielojęzyczności (na przykładzie francuskiego jako drugiego języka obcego. Lublin: Wydawnictwo Werset.

Lado, R. (1957). Linguistics Across Cultures. Ann Arbor: University of Michigan Press.

Larsen-Freeman, D. (1997). Chaos/complexity science and second language acquisition. Applied Linguistics, 18 (2), 141-165. https://doi.org/10.1093/applin/18.2.141 
Larsen-Freeman, D. (2007). Reflecting on the cognitive-social debate in second language acquisition. The Modern Language Journal, 91, 773-787. https://doi. org/10.1111/j.1540-4781.2007.00668.x

Larsen-Freeman, D. (2014). It's about time. The Modern Language Journal, 98 (2), 665-666. https://doi.org/10.1111/modl.12097

Larsen-Freeman, D., \& Cameron, L. (2008). Research methodology on language development from a complex systems perspective. The Modern Language Journal, 92 (2), 200-213. https://doi.org/10.1111/j.1540-4781.2008.00714.x

McLaughlin, B. (1978). The Monitor Model: some methodological considerations. Language Learning, 28, 309-332. https://doi.org/10.1111/j.1467-1770.1978.tb00137.x

Meisel, J. (1983). Transfer as a second language strategy. Language and Communication, 3, 11-46. https://doi.org/10.1016/0271-5309(83)90018-6

Nowikow, W. (2017). Gramática contrastiva español-polaco. Łódź: Wydawnictwo Uniwersytetu Warszawskiego.

Nowikow, W. (2013). Sobre la modalización del contenido proposicional: Contraste tipológico entre lenguas románicas y eslavas. In Antonio Pamies Bertrán (Ed.), De lingüística, traducción y lexico-fraseología. Homenaje a Juan de Dios Luque Durán (pp. 65-72). Granada: Editorial Comares.

Odlin, T. (1989). Language Transfer. Cambridge: Cambridge University Press. https://doi.org/10.1017/CBO9781139524537

Odlin, T. (2016a). Was there really ever a contrastive analysis hypothesis?. In Rosa Alonso Alonso (Ed.), Crosslinguistic influence in Second Language Acquisition (pp. 1-23). Bristol: Multilingual Matters. https://doi.org/10.21832/9781783094837-003

Odlin, T. (2016b). Language transfer and the link between comprehension and production. In Liming Yu \& Terence Odlin (Eds.), New Perspectives on Transfer in Second Language Learning (pp. 207-225). Bristol: Multilingual Matters. https://doi.org/10.21832/9781783094349-013

Otwinowska, A. (2016). Cognate Vocabulary in Language Acquisition and Use. Attitudes, Awareness, Activation. Bristol: Multilingual Matters. https://doi. org/10.21832/9781783094394

Pawlik, J. (2001). Selección de problemas de gramática española. Poznań: Wydawnictwo Naukowe UAM.

Ringbom, H. (1987). The Role of the First Language in Foreign Language Learning. Clevedon: Multilingual Matters.

Ringbom, H. (2011). Perceived redundancy or crosslinguistic influence? What L3 learners' material can tell us about the causes of errors. In Gessica De Angelis \& Jean-Marc Dewaele (Eds.), New Trends in Crosslinguistic Influence and Multilingualism Research (pp. 19-24). Bristol: Multilingual Matters https://doi. org/10.21832/9781847694430-003

Ringbom, H. (2016). Comprehension, learning and production of foreign languages: The role of transfer. In Rosa Alonso Alonso (Ed.), Crosslinguistic Influence in Second Language Acquisition (pp. 38-52). Bristol: Multilingual Matters. https://doi.org/10.21832/9781783094837-005

Robinson, E. (1927). The 'similarity' factor in retroaction. American Journal of Psychology, 39, 297-312. https://doi.org/10.2307/1415419

Robinson, P. (2001). Task complexity, task difficulty, and task production: Exploring interactions in a componential framework. Applied Linguistics, 22 (1), 27-57. https://doi.org/10.1093/applin/22.1.27

Safont Jordà, M.P. (2005). Third Language Learners: Pragmatic Production and Awareness. Clevedon: Multilingual Matters. https://doi.org/10.21832/9781853598043 
Sanchez, L. (2011). 'Luisa and Pedrito's dog will the breakfast eat': Interlanguage transfer and the role of the second language factor. In Gessica De Angelis \& Jean-Marc Dewaele (Eds.), New Trends in Crosslinguistic Influence and Multilingualism Research (pp. 86-104). Bristol: Multilingual Matters. https://doi. org/10.21832/9781847694430-007

Schmidt, R. (1990a). Interaction, acculturation, and the acquisition of communicative competence: A case study of an adult. In Nessea Wolfson \& Elliot Judd (Eds.), Sociolinguistics and Language Acquisition (pp. 137-174). Rowley: Newbury House Publishers.

Schmidt, R. (1990b). The role of consciousness in second language learning. Applied Linguistics, 11, 129-158. https://doi.org/10.1093/applin/11.2.129

Selinker, L. (1992). Rediscovering Interlanguage. London/New York: Routledge.

Sharwood-Smith, M. (1981). Consciousness-raising and the second language learner. Applied Linguistics, 2, 159-69. https://doi.org/10.1093/applin/2.2.159

Sharwood Smith, M., \& Kellerman, E. (1986). Crosslinguistic Influence in Second Language Acquisition. New York: Pergamon Institute of English.

Sima Paribakht, T., \& Bingham Wesche, M. (2016). L1 influences in L2 lexical inferencing. In Liming Yu \& Terence Odlin (Eds.), New Perspectives on Transfer in Second Language Learning (pp. 76-106). Bristol: Multilingual Matters. https:// doi.org/10.21832/9781783094349-007

Singleton, D. (1996). Crosslinguistic lexical operations and the L2 mental lexicon. In Tina Hickey \& Jenny Williams (Eds.), Language, Education and Society in a Changing World (pp. 246-252). Clevedon: Iraal/Multilingual Matters.

Singleton, D., \& Aronin, L. (2007). Multiple language learning in the light of the theory of affordances. Innovation in Language Learning and Teaching, 1 (1), 83-96. https://doi.org/10.2167/illt44.0

Skaggs, E. (1925). Further studies in retroactive inhibition. Psychology Monograph, $34(8), 1-60$.

Stevick, E. (1980). Teaching Languages: A Way and Ways. Rowley: Newbury House.

Stockwell, R., Bowen, J., \& Martin, M. (1965a). The Grammatical Structures of English and Italian. Chicago: The University of Chicago Press.

Stockwell, R., Bowen, J., \& Martin, M. (1965b). The Grammatical Structures of English and Spanish. Chicago: The University of Chicago Press.

Swain, M. (1985). Communicative competence: Some roles of comprehensible input and comprehensible output in its development. In Susan Gass \& Carolyn Madden (Eds.), Input in Second Language Acquisition (pp. 235-253). Rowley: Newbury House.

Testa, M. (2018). The psycholinguistic background of L1 Polish students of L3 Spanish. Crossroads: A Journal of English Studies, 22 (3), 69-90. https://doi. org/10.15290/cr.2018.22.3.04

Testa, M. (in press). The acquisition of Spanish articles by L1 Polish students. Neofilologia: perspektywy transdyscyplinarności.

Vildomec, V. (1971). Multilingualism. Leiden: A.W. Sijthoff.

Wardhaugh, R. (1970). The contrastive analysis hypothesis. TESOL Quarterly, 4, 12330. https://doi.org/10.2307/3586182

Williams, S., \& Hammarberg, B. (1998). Language switches in L3 production: Implications for a polyglot speaking model. Applied Linguistics, 19 (3), 295-333. https://doi.org/10.1093/applin/19.3.295

Yule, G. (2010). The Study of Language, 4th edition. Cambridge: Cambridge University Press. 
Exploring the Relation Between Psychotypologies and Article...

Annex 1.1: Group descriptives for psychotypology I (B1+B2)

\begin{tabular}{|c|c|c|c|c|c|}
\hline & Group & $\mathbf{N}$ & Mean & SD & SE \\
\hline \multirow[t]{6}{*}{ Total } & Psi1 & 19 & .371 & .184 & .042 \\
\hline & Psi2 & 53 & .483 & .274 & .038 \\
\hline & Psi3 & 32 & .485 & .294 & .052 \\
\hline & Psi4 & 40 & .428 & .224 & .035 \\
\hline & Psi5 & 27 & .386 & .217 & .042 \\
\hline & Psi6 & 45 & .494 & .273 & .041 \\
\hline \multirow[t]{6}{*}{$a$} & Psi1 & 19 & .095 & .096 & .022 \\
\hline & Psi2 & 53 & .104 & .101 & .014 \\
\hline & Psi3 & 32 & .130 & .120 & .021 \\
\hline & Psi4 & 40 & .078 & .073 & .012 \\
\hline & Psi5 & 27 & .082 & .090 & .017 \\
\hline & Psi6 & 45 & .113 & .104 & .015 \\
\hline \multirow[t]{6}{*}{$b$} & Psi1 & 19 & .144 & .077 & .018 \\
\hline & Psi2 & 53 & .132 & .109 & .015 \\
\hline & Psi3 & 32 & .149 & .080 & .014 \\
\hline & Psi4 & 40 & .125 & .115 & .018 \\
\hline & Psi5 & 27 & .140 & .092 & .018 \\
\hline & Psi6 & 45 & .132 & .108 & .016 \\
\hline \multirow[t]{6}{*}{$c$} & Psi1 & 19 & .125 & .133 & .031 \\
\hline & Psi2 & 53 & .217 & .218 & .030 \\
\hline & Psi3 & 32 & .192 & .206 & .036 \\
\hline & Psi4 & 40 & .194 & .202 & .032 \\
\hline & Psi5 & 27 & .144 & .205 & .039 \\
\hline & Psi6 & 45 & .222 & .198 & .029 \\
\hline \multirow[t]{6}{*}{$d$} & Psil & 19 & .008 & .017 & .004 \\
\hline & Psi2 & 53 & .028 & .045 & .006 \\
\hline & Psi3 & 32 & .013 & .026 & .005 \\
\hline & Psi4 & 40 & .202 & .047 & .007 \\
\hline & Psi5 & 27 & .020 & .035 & .007 \\
\hline & Psi6 & 45 & .025 & .043 & .006 \\
\hline
\end{tabular}

Annex 1.2: Group descriptives for psychotypology I (B1)

\begin{tabular}{cccccc}
\hline & Group & N & Mean & SD & SE \\
\hline Total & Psi1 & 7 & .431 & .108 & .041 \\
& Psi2 & 28 & .458 & .276 & .052 \\
\hline
\end{tabular}


Дослідження взаємозв'язків між психотипологією та вживанням...

\begin{tabular}{|c|c|c|c|c|c|}
\hline & Psi3 & 17 & .465 & .289 & .070 \\
\hline & Psi4 & 18 & .440 & .216 & .051 \\
\hline & Psi5 & 12 & .437 & .133 & .038 \\
\hline & Psi6 & 23 & .460 & .296 & .062 \\
\hline \multirow[t]{6}{*}{$a$} & Psil & 7 & .154 & .127 & .048 \\
\hline & Psi2 & 28 & .100 & .102 & .019 \\
\hline & Psi3 & 17 & .153 & .129 & .031 \\
\hline & Psi4 & 18 & .072 & .065 & .015 \\
\hline & Psi5 & 12 & .125 & .116 & .033 \\
\hline & Psi6 & 23 & .104 & .105 & .022 \\
\hline \multirow[t]{6}{*}{$b$} & Psi1 & 7 & .163 & .058 & .022 \\
\hline & Psi2 & 28 & .119 & .086 & .016 \\
\hline & Psi3 & 17 & .144 & .077 & .019 \\
\hline & Psi4 & 18 & .112 & .086 & .020 \\
\hline & Psi5 & 12 & .166 & .076 & .022 \\
\hline & Psi6 & 23 & .107 & .080 & .017 \\
\hline \multirow[t]{6}{*}{$c$} & Psi1 & 7 & .110 & .106 & .040 \\
\hline & Psi2 & 28 & .204 & .200 & .038 \\
\hline & Psi3 & 17 & .152 & .184 & .045 \\
\hline & Psi4 & 18 & .216 & .191 & .045 \\
\hline & Psi5 & 12 & .126 & .109 & .031 \\
\hline & Psi6 & 23 & .216 & .214 & .045 \\
\hline \multirow[t]{6}{*}{$d$} & Psil & 7 & .009 & .023 & .009 \\
\hline & Psi2 & 28 & .034 & .051 & .010 \\
\hline & Psi3 & 17 & .018 & .032 & .008 \\
\hline & Psi4 & 18 & .040 & .058 & .014 \\
\hline & Psi5 & 12 & .022 & .038 & .011 \\
\hline & Psi6 & 23 & .033 & .053 & .011 \\
\hline
\end{tabular}

Annex 1.3: Group descriptives for psychotypology I (B2)

\begin{tabular}{lccccc}
\hline & Group & N & Mean & SD & SE \\
\hline Total & Psi1 & 12 & .336 & .214 & .062 \\
& Psi2 & 25 & .512 & .275 & .055 \\
& Psi3 & 15 & .507 & .309 & .080 \\
Psi4 & 22 & .419 & .236 & .050 \\
& Psi5 & 15 & .346 & .265 & .068 \\
& Psi6 & 22 & .529 & .248 & .053 \\
\hline
\end{tabular}


Exploring the Relation Between Psychotypologies and Article...

\begin{tabular}{|c|c|c|c|c|c|}
\hline \multirow[t]{6}{*}{$a$} & Psi1 & 12 & .060 & .052 & .015 \\
\hline & Psi2 & 25 & .108 & .102 & .020 \\
\hline & Psi3 & 15 & .105 & .106 & .027 \\
\hline & Psi4 & 22 & .084 & .080 & .017 \\
\hline & Psi5 & 15 & .048 & .039 & .010 \\
\hline & Psi6 & 22 & .122 & .104 & .022 \\
\hline \multirow[t]{6}{*}{$b$} & Psi1 & 12 & .133 & .087 & .025 \\
\hline & Psi2 & 25 & .148 & .130 & .026 \\
\hline & Psi3 & 15 & .155 & .086 & .022 \\
\hline & Psi4 & 22 & .135 & .136 & .029 \\
\hline & Psi5 & 15 & .120 & .100 & .026 \\
\hline & Psi6 & 22 & .159 & .127 & .027 \\
\hline \multirow[t]{6}{*}{$c$} & Psil & 12 & .133 & .151 & .044 \\
\hline & Psi2 & 25 & .233 & .239 & .048 \\
\hline & Psi3 & 15 & .238 & .226 & .058 \\
\hline & Psi4 & 22 & .175 & .213 & .045 \\
\hline & Psi5 & 15 & .159 & .261 & .067 \\
\hline & Psi6 & 22 & .229 & .184 & .039 \\
\hline \multirow[t]{6}{*}{$d$} & Psi1 & 12 & .007 & .014 & .004 \\
\hline & Psi2 & 25 & .022 & .036 & .007 \\
\hline & Psi3 & 15 & .007 & .016 & .004 \\
\hline & Psi4 & 22 & .024 & .037 & .008 \\
\hline & Psi5 & 15 & .018 & .033 & .008 \\
\hline & Psi6 & 22 & .017 & .030 & .006 \\
\hline
\end{tabular}

Annex 2.1: Group descriptives for psychotypology II (B1+B2)

\begin{tabular}{cccccc}
\hline & Group & N & Mean & SD & SE \\
\hline Total & Psi7 & 6 & .400 & .265 & .108 \\
& Psi8 & 65 & .461 & .259 & .032 \\
& Psi10 & 53 & .442 & .272 & .037 \\
& Psi11 & 16 & .422 & .153 & .038 \\
& Psi13 & 14 & .351 & .159 & .043 \\
& Psi14 & 55 & .476 & .277 & .037 \\
& Psi7 & 6 & .102 & .067 & .027 \\
& Psi8 & 65 & .102 & .102 & .013 \\
& Psi10 & 53 & .099 & .102 & .014 \\
& Psi11 & 16 & .114 & .097 & .024 \\
\hline
\end{tabular}


Дослідження взаємозв'язків між психотипологією та вживанням...

\begin{tabular}{|c|c|c|c|c|c|}
\hline & Psi13 & 14 & .071 & .072 & .019 \\
\hline & Psi14 & 55 & .114 & .104 & .014 \\
\hline \multirow[t]{6}{*}{$b$} & Psi7 & 6 & .150 & .105 & .043 \\
\hline & Psi8 & 65 & .135 & .102 & .013 \\
\hline & Psi10 & 53 & .132 & .087 & .012 \\
\hline & Psi11 & 16 & .146 & .146 & .036 \\
\hline & Psi13 & 14 & .138 & .088 & .023 \\
\hline & Psi14 & 55 & .130 & .105 & .014 \\
\hline \multirow[t]{6}{*}{$c$} & Psi7 & 6 & .142 & .163 & .067 \\
\hline & Psi8 & 65 & .198 & .208 & .026 \\
\hline & Psi10 & 53 & .186 & .206 & .028 \\
\hline & Psi11 & 16 & .152 & .138 & .034 \\
\hline & Psi13 & 14 & .116 & .099 & .026 \\
\hline & Psi14 & 55 & .209 & .218 & .029 \\
\hline \multirow[t]{6}{*}{$d$} & Psi7 & 6 & .010 & .024 & .010 \\
\hline & Psi8 & 65 & .025 & .041 & .005 \\
\hline & Psi10 & 53 & .023 & .038 & .005 \\
\hline & Psi11 & 16 & .012 & .022 & .006 \\
\hline & Psi13 & 14 & .027 & .043 & .011 \\
\hline & Psi14 & 55 & .020 & .040 & .005 \\
\hline
\end{tabular}

Annex 2.2: Group descriptives for psychotypology II (B1)

\begin{tabular}{cccccc}
\hline & Group & N & Mean & SD & SE \\
\hline Total & Psi7 & 3 & .383 & .055 & .032 \\
& Psi8 & 32 & .459 & .261 & .046 \\
& Psi10 & 24 & .427 & .253 & .052 \\
& Psi11 & 9 & .420 & .161 & .054 \\
& Psi13 & 9 & .407 & .138 & .046 \\
& Psi14 & 24 & .469 & .290 & .059 \\
& Psi7 & 3 & .103 & .059 & .034 \\
& Psi8 & 32 & .112 & .112 & .020 \\
& Psi10 & 24 & .102 & .111 & .023 \\
& Psi11 & 9 & .138 & .112 & .037 \\
& Psi13 & 9 & .087 & .076 & .025 \\
& Psi14 & 24 & .129 & .117 & .024 \\
& Psi7 & 3 & .127 & .059 & .034 \\
& Psi8 & 32 & .128 & .085 & .015 \\
\hline
\end{tabular}


Exploring the Relation Between Psychotypologies and Article...

\begin{tabular}{lccccc}
\hline & & & & \\
\hline & Psi10 & 24 & .122 & .078 & .016 \\
& Psi11 & 9 & .141 & .097 & .032 \\
& Psi13 & 9 & .152 & .082 & .027 \\
& Psi14 & 24 & .108 & .074 & .015 \\
& Psi7 & 3 & .143 & .140 & .081 \\
& Psi8 & 32 & .189 & .193 & .034 \\
& Psi10 & 24 & .172 & .174 & .036 \\
& Psi11 & 9 & .132 & .137 & .046 \\
& Psi13 & 9 & .140 & .113 & .038 \\
& Psi14 & 24 & .205 & .212 & .043 \\
& Psi7 & 3 & .020 & .035 & .020 \\
& Psi8 & 32 & .030 & .049 & .009 \\
& Psi10 & 24 & .030 & .043 & .009 \\
& Psi11 & 9 & .013 & .026 & .009 \\
& Psi13 & 9 & .030 & .042 & .014 \\
& Psi14 & 24 & .027 & .051 & .010 \\
\hline
\end{tabular}

Annex 2.3: Group descriptives for psychotypology II (B2)

\begin{tabular}{lccccc}
\hline & Group & N & Mean & SD & SE \\
\hline Total & Psi7 & 3 & .417 & .415 & .240 \\
& Psi8 & 33 & .463 & .262 & .046 \\
& Psi10 & 29 & .454 & .291 & .054 \\
& Psi11 & 7 & .424 & .155 & .059 \\
& Psi13 & 5 & .250 & .156 & .070 \\
& Psi14 & 31 & .481 & .271 & .049 \\
& Psi7 & 3 & .100 & .089 & .051 \\
& Psi8 & 33 & .093 & .093 & .016 \\
& Psi10 & 29 & .097 & .096 & .018 \\
& Psi11 & 7 & .084 & .069 & .026 \\
& Psi13 & 5 & .042 & .060 & .027 \\
& Psi14 & 31 & .103 & .092 & .017 \\
& Psi7 & 3 & .173 & .150 & .087 \\
& Psi8 & 33 & .142 & .118 & .020 \\
& Psi10 & 29 & .140 & .094 & .018 \\
& Psi11 & 7 & .153 & .201 & .076 \\
& Psi13 & 5 & .112 & .101 & .045 \\
& Psi14 & 31 & .147 & .122 & .022 \\
\hline
\end{tabular}


Дослідження взаємозв'язків між психотипологією та вживанням...

\begin{tabular}{lccccc}
\hline$c$ & Psi7 & 3 & .140 & .217 & .125 \\
& Psi8 & 33 & .207 & .224 & .039 \\
& Psi10 & 29 & .197 & .232 & .043 \\
& Psi11 & 7 & .177 & .146 & .055 \\
& Psi13 & 5 & .072 & .054 & .024 \\
& Psi14 & 31 & .213 & .226 & .041 \\
& Psi7 & 3 & .000 & .000 & .000 \\
& Psi8 & 33 & .019 & .032 & .006 \\
& Psi10 & 29 & .018 & .033 & .006 \\
& Psi11 & 7 & .010 & .017 & .007 \\
& Psi13 & 5 & .022 & .049 & .022 \\
& Psi14 & 31 & .015 & .028 & .005 \\
\hline
\end{tabular}

\section{АННОТАЦИЯ}

Цель исследования заключается в изучении вопроса о существовании связи между психотипологией (как очевидным отличием языков) и количеством ошибок, связанных с употреблением испанских артиклей польскими студентами с языковым уровнем L1, которые владеют испанским языком на уровне L3. Статья освещает исследование оценки респондентами осознаваемых языковых различий на уровне ведущих языковых конструкций, ошибок, касающихся применения артиклей. Это было выяснено с помощью использования батареи непараметрических U-критериев Манна-Уитни. Полученные результаты не свидетельствуют о наличии достоверных различий между исследуемыми группами В1 и В2 по применению артиклей. Однако положительные корреляции были найдены на общем уровне В1+B2 между грамматической психотипологиею и ошибками, которые проявлялись в отсутствии артиклей, а также в группе В2 по общему употреблению артиклей и, более конкретно, некорректного использования артиклей и ошибок в виде их пропусков. С другой стороны, были обнаружены негативные корреляции между лексической психотипологией и использованием артиклей в группе В2; фонетической психотипологией и неправильным использованием артиклей в группе В1, грамматической психотипологиею и ненужным использованием артиклей в группе В1.

Полученные результаты позволяют предположить, что очевидное различие языков среди более опытных учеников может быть связана с успешным развитием кросс-лингвистических ассоциаций, в то время как указанное может вызывать ошибочное восприятие указанного отличия на более низких уровнях обучения.

Ключевые слова: психолингвистика, психотипология, овладение артиклями, L3 уровень испанского языка, L1 уровень польского языка. 
Exploring the Relation Between Psychotypologies and Article...

Теста Мартін. Дослідження взаємозв'язків між психотипологією та вживанням артиклів

\begin{abstract}
АНОТАЦІЯ
Ціль дослідження полягає у вивченні питання щодо існування зв'язку між психотипологією (як очевидною відмінністю мов) та кількістю помилок пов'язаних із вживання іспанських артиклів польськими студентами з мовним рівнем L1, які користуються іспанською мовою на рівні L3. Cтаття містить дослідження оцінки учасниками усвідомлюваних мовних відмінностей на рівні провідних мовних конструкцій, помилок, що стосуються застосування артиклів, що було з'ясовано за допомогою використанням батареї непараметричних U-критеріїв Манна-Уітні. Отримані результати не засвідчують наявність достовірних відмінностей між досліджуваними групами В1 та В2 щодо застосування артиклів. Проте позитивні кореляції були знайдені на загальному рівні В1+В2 між граматичною психотипологією та помилками, що виявлялися у відсутності артиклів, а також у групі В2 щодо загального вжитку артиклів и, більш конкретно, некоректного використання артиклів та помилок у вигляді їх пропусків. 3 іншого боку, було виявлено негативні кореляції між лексичною психотипологією та використанням артиклів у групі В2; фонетичною психотипологією і невірним використанням артиклів у групі В1, граматичною психотипологією і непотрібним використанням артиклів у групі В1.

Отримані результати дозволяють припустити, що очевидна відмінність мов посеред більш досвідчених учнів може бути пов'язаною з успішним розвитком кросс-лінгвістичних асоціацій, у той час як зазначене може зумовлювати помилкове сприйняття вказаної відмінності на більш низьких рівнях навчання.
\end{abstract}

Ключові слова: психолінгвістика, психотипологія, оволодіння артиклями, L3 рівень іспанської мови, L1 рівень польської мови. 